\title{
Functional Comparison of Bone Marrow-Derived Liver Stem Cells: Selection Strategy for Cell-Based Therapy
}

\author{
Daniel Inderbitzin, M.D., Itzhak Avital, M.D., Beat Gloor, M.D., Adrian Keogh, Ph.D., \\ Daniel Candinas, M.D.
}

\begin{abstract}
Several distinct subpopulations of bone marrow-derived liver progenitor cells were recently described. However, there is inadequate information comparing these subpopulations from a liver-function point of view. This study was undertaken to compare two subpopulations of liver progenitors: $\beta_{2}$-microglobulin $\left(\beta_{2} \mathrm{~m}\right)$-negative/Thy-1-positive cells, and liver progenitors obtained from the non-adherent cell fraction after a panning procedure. The cells were cultured under several conditions including high- and lowdose hepatocyte growth factor, various cellular densities, and different media. Growth characteristics, liver-specific metabolic capacity, and liver regeneration-associated gene expression were studied. Both isolation procedures yielded cells that produced albumin and metabolized ammonia into urea. The study demonstrated that the $\beta_{2} \mathrm{~m}$-negative/Thy-1-positive cell fraction metabolized ammonia into urea more efficiently and produced a superior amount of albumin compared with the panned cell fraction. The $\beta_{2} \mathrm{~m}$-negative/Thy-1-positive cell fraction could be optimal for the development of novel cell-based treatment strategies for congenital or acquired liver diseases. (J GASTROINTEST SuRG 2005;9:13401345) (c) 2005 The Society for Surgery of the Alimentary Tract
\end{abstract}

KEY WORDS: Hepatic stem cells, cell biology, metabolism, in vitro study, rodent

Bone marrow-derived cells can differentiate into hepatocytes, cholangiocytes, and hepatic endothelial cells under specific conditions. ${ }^{1-11}$ Recently, several studies demonstrated that bone marrow-derived adult liver stem cells could be activated and mobilized from the bone marrow, on a specific demand, generated by a failing liver. After activation, these cells demonstrated exquisite ability to differentiate into several cell lineages and provide hepatic support. ${ }^{5,8,12,13}$ Consequently, this plasticity of adult bone marrow cells elicited renewed enthusiasm in developing novel treatment strategies for the caring of congenital and acquired liver diseases. ${ }^{14}$ One potential advantage of such an adult liver progenitor cell is the possibility of use in an autogenic manner, avoiding immunosuppression.

Currently, bone marrow-derived liver progenitors are thought to be a heterogeneous group of cells. This bone marrow fraction of cells is composed of several different subpopulations, as reflected by the diverse experimental strategies for their isolation, characterization, and culturing. ${ }^{1,6,9,10,15-18}$ Adopting the concept of a single pluripotent adult stem cell, residing within the bone marrow, that carries a potential capability to generate progeny of several lineages with hepatocyte-associated function gave the impetus to the search for an optimal subpopulation of cells that should be used to develop novel cell therapy strategies.

As published recently by Oh et al., ${ }^{16}$ a subpopulation of putative liver progenitor cells can be isolated from the bone marrow by a panning procedure. When cultured for 21 days with initially high doses of hepatocyte growth factor (HGF), these bone marrow cells transformed into a hepatocyte lineage as shown by the expression of albumin mRNA. In a similar approach, Miyazaki et al. $^{6}$ were able to induce hepatocyte-specific mRNA expression in

Presented at the Forty-Sixth Annual Meeting of The Society for Surgery of the Alimentary Tract, Chicago, IL, May 14-18, 2005 (poster presentation).

From the Department of Visceral and Transplant Surgery (D.I., B.G., A.K., D.C.), University Hospital Bern, Bern, Switzerland; and the Department of Surgery (I.A.), Memorial Sloan-Kettering Cancer Center, New York, New York.

Reprint requests: Daniel Inderbitzin, M.D., Department of Visceral and Transplant Surgery, University Hospital Bern, CH-3010 Bern, Switzerland. e-mail: daniel.inderbitzin@insel.ch 
nonsorted bone marrow cells by the addition of HGF to the culture media.

A different approach to isolate adult liver progenitor cells from the bone marrow was developed by our group. 1,15 After a two-step magnetic cell sorting (MACS) immunoisolation procedure, $\beta_{2^{-}}$ microglobulin-negative, Thy-1 (CD-90)-positive ( $\beta_{2} \mathrm{~m}$-negative/Thy-1-positive) cells (rodent and human) were shown to express hepatocyte-specific markers. Additionally, their hepatocyte-specific metabolic activity was detectable both in culture and in vivo. . $^{1,5,11,15}$

The aim of this study was to further characterize and functionally compare these two promising progenitor cell subpopulations. Prior to embarking on developing novel cell therapy strategies for the care of patients with failing livers, it is imperative to select the optimal cell source. We demonstrate here that the $\beta_{2} \mathrm{~m}$-negative/Thy-1-positive cell fraction is an attractive candidate to be used in such novel cell therapies.

\section{MATERIAL AND METHODS}

All animal experimentation was approved by the institutional committee for animal welfare in accordance with the European Convention on Animal Care. Twenty-eight male Sprague-Dawley rats (220250 g; RCC Ltd., Füllinsdorf, Switzerland) were divided into seven experimental groups (Table 1). Cells from rat's bone marrow were isolated either by panning or by MACS, as described previously. ${ }^{1,15,16}$ Cells were then either plated onto a low- or a highdensity cellular culture on uncoated polystyrene dishes or onto a layer of Matrigel (Becton Dickinson, Bedfold, MA). ${ }^{1,15,16}$ Culture medium was either DF medium, a 1:1 mixture of Ham's F12 (GIBCO,
Invitrogen Corporation, Paisley, Scotland, UK) and Dulbecco's modified Eagle's medium (Sigma, Buchs, Switzerland) supplemented with $1000 \mathrm{ng} / \mathrm{ml}$ of HGF (R\&D Systems, Minneapolis, MN) for 5 days, followed by $5 \mathrm{ng} / \mathrm{ml}$ of HGF or DF medium supplemented with $20 \mathrm{ng} / \mathrm{ml}$ of HGF for the entire culture period of 12 days. Alternatively cells were cultured in small hepatocyte media $(\mathrm{SHM})^{19}$ with $10 \%$ heat-inactivated fetal calf serum (Invitrogen, Basel, Switzerland) and supplemented with HGF (20 $\mathrm{ng} / \mathrm{ml})$ and epidermal growth factor $(10 \mathrm{ng} / \mathrm{ml}$; Biosource, Camarillo, CA). The cells were cultured in $500 \mu \mathrm{l}$ of media for 12 days with a change of medium every third day.

\section{The Panning Procedure}

Femoral bone marrow was harvested by aspiration through an 18-gauge needle (Venflon; Becton Dickinson, Fraga, Spain) with a 1-ml syringe (Plastipak; Becton Dickinson, Madrid, Spain) and transferred into sterile phosphate-buffered saline. The bone marrow pellet was gently drawn into and expelled from the syringe 10 times to release the cells into suspension. After red cell lysis, the remaining cells were precultured in DF medium supplemented with $10 \%$ fetal bovine serum on a $60-\mathrm{mm}$ polystyrene dish (Corning Costar Corporation, Bodenheim, Germany). ${ }^{16}$ After 60 minutes of panning, the nonadherent cells were collected, washed with serum-free DF medium, and plated.

\section{The MACS Procedure}

For the isolation of $\beta_{2}$ m-negative/Thy-1-positive cells, the recently developed MACS procedure was used as described recently by Avital et al. ${ }^{15}$ and Inderbitzin et al. ${ }^{1}$

Table 1. Experimental Groups

\begin{tabular}{llcccc}
\hline $\begin{array}{l}\text { Experimental } \\
\text { Group }\end{array}$ & $\begin{array}{c}\text { Cell Isolation } \\
\text { Procedure }\end{array}$ & $\begin{array}{c}\text { Cells } \\
\text { Plated/cm }\end{array}$ & $\begin{array}{c}\text { Coating of } \\
\text { Culture Dishes }\end{array}$ & $\begin{array}{c}\text { Culture } \\
\text { Medium }\end{array}$ & Hepatocyte Growth Factor \\
\hline PaL20 & Panning & 5000 & None & DF medium & $20 \mathrm{ng} / \mathrm{ml}$ \\
MaL20 & MACS & 5000 & None & DF medium & $20 \mathrm{ng} / \mathrm{ml}$ \\
PaL1000 & Panning & 5000 & None & DF medium & $1000 \mathrm{ng} / \mathrm{ml} ;>\mathrm{day} 6: 5 \mathrm{ng} / \mathrm{ml}$ \\
MaL1000 & MACS & 5000 & None & DF medium & $1000 \mathrm{ng} / \mathrm{ml} ;>\mathrm{day} 6: 5 \mathrm{ng} / \mathrm{ml}$ \\
PaH1000 & Panning & 50,000 & None & DF medium & $1000 \mathrm{ng} / \mathrm{ml} ;>\mathrm{day} 6: 5 \mathrm{ng} / \mathrm{ml}$ \\
PaHSHM & Panning & 50,000 & Matrigel & SHM & $20 \mathrm{ng} / \mathrm{ml}$ \\
MaHSHM & MACS & 50,000 & Matrigel & SHM & $20 \mathrm{ng} / \mathrm{ml}$ \\
\hline
\end{tabular}

Subpopulations of bone marrow cells were isolated by two different procedures: panning ( $\mathrm{Pa}$ ) and magnetic cell sorting of $\boldsymbol{\beta}_{2}$-microglobulin negative/Thy-1-positive cells $(\mathrm{Ma})$. The cells were plated using two different cell densities: $\mathrm{L}=5000 \mathrm{cells} / \mathrm{cm}^{2}, \mathrm{H}=50,000 \mathrm{cells} / \mathrm{cm}^{2}$, on uncoated polystyrene dishes or on a layer of Matrigel, in small hepatocyte medium (SHM) or a mixure of Dulbecco's modified Eagle medium and Ham's-F12 medium (DF medium) containing $1000 \mathrm{ng} / \mathrm{ml}$ (1000) of hepatocyte growth factor for 5 days and $5 \mathrm{ng} / \mathrm{ml}$ thereafter, or $20 \mathrm{ng} / \mathrm{ml}$ (20) of HGF for the entire culture period. 


\section{Matrigel Coating of Polystyrene Culture Dishes}

For all culture experiments, 24-well cell culture plates were used (Corning Costar Corporation). Where indicated, dishes were coated with a gel layer of Matrigel $\left(25 \mu \mathrm{g} / \mathrm{cm}^{2}\right) .{ }^{1,15}$

\section{Enzyme-Linked Immunosorbent Assay (Albumin)}

Albumin secretion was measured at culture days 3, 6,9 , and 12 by sandwich enzyme-linked immunosorbent assay. Samples were analyzed in several dilutions $(1: 1,1: 2,1: 5,1: 10)$ and compared with a standard curve of rat albumin (RSA, Rat albumin fraction V; ICN Biomedicals GmbH, Eschwege, Germany). ${ }^{20}$

\section{Determination of Urea Synthesis}

Bone marrow derived liver progenitors were spiked with ammonia (Sigma A 4514, $2.5 \mathrm{mmol} / \mathrm{l}$, $\mathrm{pH} 7.40$ ) for 5 hours at 3, 6, 9, and 12 days of culturing. Ammonia and urea content were then immediately determined by the use of an enzymatic colorimetric method (Roche Diagnostics, Rotkreuz, Switzerland). The precision of the test in the described experimental setting is $\pm 2.6 \%$ for ammonia and $\pm 2.7 \%$ for urea. ${ }^{1,21}$

\section{Total RNA Extraction}

Cells were harvested by addition of $500 \mu$ of TRIZOL (Invitrogen AG) to the culture dish after complete removal of the media immediately after determination of urea formation. Total RNA was extracted as described previously, ${ }^{22}$ and cDNA then was synthesized with random primers, using the Promega Reverse Transcription System (Promega Corporation, Madison, WI).

\section{Albumin, Multidrug Resistance Associated Protein-1 (mrp-1), Multidrug Resistance Associated Protein-2 (mrp-2) mRNA Expression}

Quantitative mRNA expression was measured by TaqMan real-time polymerase chain reaction (PCR) using albumin, mrp-1, and mrp-2 primers and probes as described. ${ }^{1,19}$ Standard TaqMan real-time PCR conditions (Applied Biosystems, Rotkreuz, Switzerland) were used. The cycler conditions were set to $50^{\circ} \mathrm{C}$ for 2 minutes, followed by 50 cycles of the amplification step $\left(95^{\circ} \mathrm{C}\right.$ for 15 seconds to activate the Taq DNA polymerase and $60^{\circ} \mathrm{C}$ for 15 seconds to anneal and extend the amplicon).

\section{S rRNA Content}

The content of $18 \mathrm{~S}$ rRNA in each individual culture dish was quantified by TaqMan real-time PCR (AB Applied Biosystems). Average threshold cycle values (CT values) from triplicate real-time PCRs were obtained. Standardization of the metabolic signal (e.g., urea formation or albumin secretion) for total cell number was achieved by the following formula: (Metabolic signal/hr)/ $\left(2^{\exp (50-\mathrm{CT} \text { value of } 18 \mathrm{~S} \text { rRNA })}\right){ }^{1,23} \mathrm{CT}$ values of the gene of interest were related to $18 \mathrm{~S}$ rRNA content: $(\Delta C T$ gene of interest $=C T$ gene of interest CT 18S rRNA).

\section{Statistical Analysis}

Results are expressed as mean \pm SD. Paired $t$ test was used to compare parallel cell cultures from the same donor animal. Student's $t$ test was applied to compare groups with normally distributed data. For the correction of pairwise multiple comparisons, the Student-Newman-Keuls method was applied. The significance level was set at $P<.05$.

\section{RESULTS}

In the first experiment, we examined whether $\beta_{2}$ m-negative/Thy-1-positive cells attach within 60 minutes to a polystyrene culture dish. Of the cells plated, $16.7 \% \pm 5.5 \%(\mathrm{n}=5)$ were nonadherent and accordingly harvested in suspension, as described previously after the panning procedure. In a subsequent experiment, using the MACS procedure on the nonadherent cell fraction, $6.5 \% \pm 1.5 \%$ of cells were identified as $\beta_{2} \mathrm{~m}$-negative/Thy-1-positive.

\section{ATP Binding Cassette Transporter Gene Expression (mrp-1, mrp-2)}

mrp-1 was expressed in both subpopulations (i.e., after panning and after the MACS procedure) immediately after isolation. The corresponding $\Delta \mathrm{CT}$ values for mrp-1 were $13.7 \pm 0.2$ for panned cells and $12.9 \pm 3.4$ for $\beta_{2}$ m-negative/Thy-1positive cells. After culturing, mrp-1 expression was maintained in the PaHSHM group (see Table 1) for 12 days of culture (average $\Delta \mathrm{CT}$ values, $11.5 \pm 0.7$ ). In contrast, in the MaHSHM group the mrp-1 signal was not detectable.

No expression of mrp-2 mRNA was found in realtime PCR in freshly isolated or cultured cells from both cell isolation methods. 


\section{Experimental Groups With Low Density of Plated Cells}

Analyzing the total cell number of parallel cell cultures (i.e., PaL20 with PaL1000; MaL20 with MaL1000) in culture media containing different amounts of HGF revealed no significant difference in the panned groups, whereas cell number in the MACS groups was significantly decreased in the culture media with high HGF content (Table 2). Albumin secretion or urea genesis was not detectable in any of these four experimental conditions (Table 3). Of note, high doses of HGF significantly reduced the total amount of $\beta_{2}$ m-negative/Thy-1-positive cells in culture, whereas no change in total cell number was detected in the cells after panning.

\section{Experimental Groups With High Density of Plated Cells}

Pairwise comparison of $18 \mathrm{~S}$ rRNA content in the high-density cultures (PaHSHM, PaH, MaSHM) showed significant differences in the total number of cells between all groups (Table 2). The highest cell number was observed in panned cells cultured on Matrigel in SHM (PaHSHM). Cell number was stable over a culture period of 12 days (Table 2). Urea genesis was maintained for 12 days and albumin synthesis was detectable in the culture media until culture day 9 (Table 3). The metabolic capacity of the panned subpopulation on Matrigel in SHM contrasts with the absence of any albumin formation or urea genesis in the $\mathrm{PaH} 1000$ group.

Table 2. Average 18S rRNA Content in Each Individual Culture

\begin{tabular}{lcccc}
\hline \multirow{2}{*}{$\begin{array}{l}\text { Experimental } \\
\text { group }\end{array}$} & \multicolumn{4}{c}{ Average CT values for } \\
\cline { 2 - 5 } & $\mathbf{3}$ days & $\mathbf{6}$ days & $\mathbf{9}$ days & $\mathbf{1 2}$ days \\
\hline PaL20 & $33 \pm 1.9$ & $31 \pm 2.7$ & $33 \pm 1.7$ & $33 \pm 2.2$ \\
MaL20 & $32 \pm 3.0$ & $32 \pm 2.2$ & $33 \pm 2.7$ & $34 \pm 4.7$ \\
PaL1000 & $32 \pm 2.6$ & $31 \pm 3.4$ & $33 \pm 2.4$ & $31 \pm 2.5$ \\
MaL1000 & $37 \pm 1.3$ & $35 \pm 6.3$ & $36 \pm 0.9$ & $36 \pm 1.8$ \\
PaH1000 & $28 \pm 1.2$ & $30 \pm 5.0$ & $29 \pm 1.8$ & $29 \pm 0.5$ \\
PaHSHM & $26 \pm 0.7$ & $25 \pm 0.6$ & $28 \pm 0.6$ & $25 \pm 4.0$ \\
MaHSHM & $34 \pm 0.7$ & $35 \pm 0.6$ & $37 \pm 1.4$ & $37 \pm 1.8$ \\
\hline
\end{tabular}

For groups, see Table 1 footnotes.

No significant cell growth or cell loss was detected under any of the seven experimental conditions examined over a period of 12 days. In the low-density (L) cultures, high doses of hepatocyte growth factor significantly reduced the total amount of cells in the groups after MACS sorting (MaL20 versus MaL1000). Total cell numbers in all three high-density $(\mathrm{H})$ cultures (PaH1000, PaHSHM, MaHSHM) were significantly different, indicating individual responses of the isolated subpopulations to the different culture conditions.
Table 3. Hepatocyte Specific Metabolic Activity

\begin{tabular}{lccc}
\hline Experimental & $\begin{array}{c}\text { Albumin } \\
\text { Expression } \\
\text { Group }\end{array}$ & $\begin{array}{c}\text { Albumin } \\
\text { Secretion: } \\
\text { Detection } \\
\text { Limit (DL): } \\
<\mathbf{1 ~ n g / m l}\end{array}$ & $\begin{array}{c}\text { Urea } \\
\text { Genesis: } \\
\text { Detection } \\
\text { Limit (DL): } \\
<\mathbf{0 . 8} \boldsymbol{\mu \mathbf { g } / \mathbf { m l }}\end{array}$ \\
\hline PaL20 & ND & $<\mathrm{DL}$ & $<\mathrm{DL}$ \\
MaL20 & ND & $<\mathrm{DL}$ & $<\mathrm{DL}$ \\
PaL1000 & $\mathrm{ND}$ & $<\mathrm{DL}$ & $<\mathrm{DL}$ \\
MaL1000 & $\mathrm{ND}$ & $<\mathrm{DL}$ & $<\mathrm{DL}$ \\
PaH1000 & + & $<\mathrm{DL}$ & $<\mathrm{DL}$ \\
PaHSHM & + & + & + \\
MaHSHM & + & + & + \\
\hline
\end{tabular}

For groups, see Table 1 footnotes.

Albumin secretion and urea genesis were determined in the seven experimental groups. Only the high-density cultures on a layer of Matrigel in small hepatocyte media showed albumin secretion (+) and urea formation $(+)$. High doses of hepatocyte growth factor induced albumin mRNA expression in bone marrow cells after panning as described, but no urea synthesis or albumin secretion was observed in this group ( $<\mathrm{DL}$, values below detection limit). Albumin mRNA was not determined (ND) in the metabolically quiescent experimental groups.

An intermediate cell number was seen in panned cells cultured in DF medium with an initial amount of $1000 \mathrm{ng} / \mathrm{ml}$ of HGF for 5 days (PaH1000). Cell number was maintained over a total of 12 days in culture (Table 2). Reduction of the HGF supplemented to $5 \mathrm{ng} / \mathrm{ml}$ did not influence the total amount of cells in culture. With real-time PCR analysis, albumin mRNA was detectable in minute amounts in the $\mathrm{PaH} 1000$ group over time, but no albumin secretion or urea formation was detectable in the metabolic assays used (Table 3).

The lowest cell number was determined in the cell cultures of $\beta_{2}$ m-negative/Thy-1-positive cells in SHM (MaHSHM). Total cell number was maintained over time with a slight decrease after day 9 in culture (Table 2). Albumin synthesis and urea formation were evident over the entire culture period of 12 days (Table 3).

\section{DISCUSSION}

The $\beta_{2}$ m-negative/Thy-1-positive bone marrow cells do not attach efficiently to a polystyrene dish. In fact, $\beta_{2}$ m-negative/Thy-1-positive cells can be enriched by the panning procedure alone in the nonadherent cell fraction by an average of around $240 \%$. ${ }^{1}$

mrp-1 expression in normal liver is low. ${ }^{24}$ However, in regenerating livers ${ }^{25}$ and in rodent livers after an oval cell induction protocol, mrp-1 specific staining was observed. ${ }^{24} \mathrm{We}$ therefore 
studied mrp-1 expression by real-time PCR in the bone marrow subpopulations obtained by panning and after the MACS procedure. mrp-1 was expressed in both subpopulations immediately after isolation. The mrp-1 signal was then maintained only in the PaHSHM group for the entire culture period of 12 days. It is possible that the cells obtained after MACS have more "liver-like" gene expression and therefore express less mrp-1.

mrp-2 is expressed in the canalicular membrane of highly differentiated hepatocytes. ${ }^{19}$ No expression of mrp-2 mRNA was found in real-time PCR in freshly isolated or cultured cells from both cell isolation methods. This is congruent with our assumption that both populations of cells are not well differentiated. Moreover, due to the lack of expression of mrp-1 and mrp-2 in the MaHSHM subpopulation, containing freshly isolated $\beta_{2} \mathrm{~m}$-negative/Thy-1positive cells, we submit that this subpopulation of cells after culturing in SHM contain cells in a lessdifferentiated state.

Bone marrow subpopulations obtained by different cell isolation procedures ${ }^{1,6-10,17,18,26}$ are likely to overlap and the amount of liver progenitor cells contained within these individual cell isolations could therefore vary considerably. Careful surface marker and liver specific functional analysis of the various cell populations physiologically present in the bone marrow is urgently needed.

To compare the liver specific functional capacity and the individual response of the two subpopulations to HGF, a series of in vitro studies were performed (Table 1).

As described by $\mathrm{Oh}$ et al., ${ }^{16}$ the panning cell isolation procedure yields a subpopulation of cells from the bone marrow that expresses albumin $\mathrm{mRNA}$ when cultured with high doses of HGF. However, in our series the high content of HGF in the DF medium did not propagate hepatocyte specific metabolic activities as demonstrated by the lack of albumin synthesis or urea formation. In a direct comparison, $\beta_{2} \mathrm{~m}$-negative/Thy-1-positive cells (MaHSHM) outperformed the panned cells (PaHSHM) significantly (Table 4). Albumin expression on the mRNA level corresponded well with the albumin secretion determined in the culture medium. The culture medium described induces strong hepatocyte specific metabolic activity in a pure culture of $\beta_{2}$ m-negative/Thy1-positive bone marrow cells. A 1:20 co-culture of $\beta_{2}$ m-negative/Thy-1-positive cells with uncharacterized bone marrow cells (PaHSHM) resulted in rapid loss of the liver specific metabolic capacity while total cell number was maintained.

High doses of $\mathrm{HGF}^{6,16}$ significantly reduced the total amount of $\beta_{2} \mathrm{~m}$-negative/Thy-1-positive cells
Table 4. Direct Metabolic Comparison of Cultured Adult Progenitor Cells Isolated by Either panning or MACS

\begin{tabular}{|c|c|c|c|}
\hline \multirow[b]{2}{*}{$\begin{array}{l}\text { Culture } \\
\text { Day }\end{array}$} & \multicolumn{3}{|c|}{$\begin{array}{c}\text { Relation of the Hepatocyte } \\
\text { Specific Metabolic Signal PaHSHM:MaHSHM }\end{array}$} \\
\hline & $\begin{array}{c}\text { Albumin Expression } \\
\text { (mRNA)* }\end{array}$ & $\begin{array}{l}\text { Albumin } \\
\text { Secretion* }\end{array}$ & $\begin{array}{c}\text { Urea } \\
\text { Genesis }\end{array}$ \\
\hline 3 & $1: 770$ & $1: 310$ & $1: 250$ \\
\hline 6 & $1: 1200$ & $1: 1750$ & $1: 530$ \\
\hline 9 & $1: 1200$ & $1: 1380$ & $1: 720$ \\
\hline 12 & $1: 1600$ & $>1: 2000$ & $1: 1070$ \\
\hline
\end{tabular}

The direct comparison of the hepatocyte specific metabolic activity between cell populations obtained after panning (PaHSHM) and after immunoisolation by magnetic cell sorting (MaHSHM) at culture days $3,6,9$, and 12 showed significantly higher metabolic capacity of the $\boldsymbol{\beta}_{2}$-microglobulin-negative, Thy-1-positive bone marrow cells in culture $\left({ }^{*} P<0.05\right)$. Albumin mRNA expression and albumin secretion paralleled in both experimental groups.

in culture while no change in total cell number was detected in the cells after panning. We concluded that high-dose HGF is potentially toxic to $\beta_{2} \mathrm{~m}$ negative/Thy-1-positive cells, whereas it has lesser effect on the panned cell population. One explanation could be based on the heterogeneity of the panned cells.

Characterizing hormonally defined culture media for unlimited cell expansion of $\beta_{2} \mathrm{~m}$-negative/Thy-1positive cells represents the next crucial step for the development of future cell-based liver therapy.

\section{CONCLUSION}

Both cell isolation procedures yielded a subpopulation of bone marrow-derived liver progenitors capable of hepatocyte specific metabolic activity. Pure cell preparation of $\beta_{2} \mathrm{~m}$-negative/Thy-1-positive cells showed significantly stronger albumin synthesis and urea formation than did cells after panning. Culture conditions to propagate the unlimited cell expansion of liver progenitor cells would make it possible to use this cell pool for the development of novel adult progenitor cell-based treatment strategies. This approach might prove to be clinically valuable for the cure of congenital or acquired liver diseases.

\section{REFERENCES}

1. Inderbitzin D, Avital I, Keogh A, et al. Interleukin-3 induces hepatocyte-specific metabolic activity in bone marrowderived liver stem cells. J GaSTROINTEST SuRG 2005;9:69-74.

2. Alison MR, Poulsom R, Jeffery R, et al. Hepatocytes from non-hepatic adult stem cells. Nature 2000;406:257. 
3. Petersen BE, Bowen WC, Patrene KD, et al. Bone marrow as a potential source of hepatic oval cells. Science 1999;284: 1168-1170.

4. Krause DS, Theise ND, Collector MI, et al. Multi-organ, multi-lineage engraftment by a single bone marrow-derived stem cell. Cell 2001;105:369-377.

5. Avital I, Feraresso C, Aoki T, et al. Bone marrow-derived liver stem cell and mature hepatocyte engraftment in livers undergoing rejection. Surgery 2002;132:384-390.

6. Miyazaki M, Akiyama I, Sakaguchi M, et al. Improved conditions to induce hepatocytes from rat bone marrow cells in culture. Biochem Biophys Res Commun 2002;298:24-30.

7. Yamamoto N, Terai S, Ohata S, et al. A subpopulation of bone marrow cells depleted by a novel antibody, anti-Liv8, is useful for cell therapy to repair damaged liver. Biochem Biophys Res Commun 2004;313:1110-1118.

8. Tanabe Y, Tajima F, Nakamura Y, et al. Analyses to clarify rich fractions in hepatic progenitor cells from human umbilical cord blood and cell fusion. Biochem Biophys Res Commun 2004;324:711-718.

9. Okumoto K, Saito T, Hattori E, et al. Differentiation of bone marrow cells into cells that express liver-specific genes in vitro: implication of the Notch signals in differentiation. Biochem Biophys Res Commun 2003;304:691-695.

10. Wang PP, Wang JH, Yan ZP, et al. Expression of hepatocyte-like phenotypes in bone marrow stromal cells after HGF induction. Biochem Biophys Res Commun 2004; 320:712-716.

11. Wang C, Chelly MR, Chai N, et al. Transcriptomic fingerprinting of bone marrow-derived hepatic beta $2 \mathrm{~m}-/$ Thy-1 + stem cells. Biochem Biophys Res Commun 2005; 327:252-260.

12. Fujii H, Hirose T, Oe S, et al. Contribution of bone marrow cells to liver regeneration after partial hepatectomy in mice. J Hepatol 2002;36:653-659.

13. Oh SH, Hatch HM, Petersen BE. Hepatic oval 'stem' cell in liver regeneration. Semin Cell Dev Biol 2002;13:405-409.

14. Orkin SH. Stem cell alchemy. Nat Med 2000;6:1212-1213.

15. Avital I, Inderbitzin D, Aoki T, et al. Isolation, characterization, and transplantation of bone marrow-derived hepatocyte stem cells. Biochem Biophys Res Commun 2001;288:156-164.

16. Oh SH, Miyazaki M, Kouchi H, et al. Hepatocyte growth factor induces differentiation of adult rat bone marrow cells into a hepatocyte lineage in vitro. Biochem Biophys Res Commun 2000;279:500-504.

17. Schwartz RE, Reyes M, Koodie L, et al. Multipotent adult progenitor cells from bone marrow differentiate into functional hepatocyte-like cells. J Clin Invest 2002;109: 1291-1302.

18. Yamazaki S, Miki K, Hasegawa K, Sata M, Takayama T, Makuuchi M. Sera from liver failure patients and a demethylating agent stimulate transdifferentiation of murine bone marrow cells into hepatocytes in coculture with nonparenchymal liver cells. J Hepatol 2003;39:17-23.

19. Sidler Pfandler MA, Hochli M, Inderbitzin D, Meier PJ, Stieger B. Small hepatocytes in culture develop polarized transporter expression and differentiation. J Cell Sci 2004; 117:4077-4087.

20. Holzman MD, Rozga J, Neuzil DF, Griffin D, Moscioni AD, Demetriou AA. Selective intraportal hepatocyte transplantation in analbuminemic and Gunn rats. Transplantation 1993;55:1213-1219.

21. Bergmeyer HU, Beutler HO. Methods of Enzymatic Analysis, 3rd ed. Deerfield Beach, FL/Basel: Verlag Chemie Weinheim, 1985, pp 454-461.

22. Chomczynski P, Sacchi N. Single-step method of RNA isolation by acid guanidinium thiocyanate-phenol-chloroform extraction. Anal Biochem 1987;162:156-159.

23. Bas A, Forsberg G, Hammarstrom S, Hammarstrom ML. Utility of the housekeeping genes $18 \mathrm{~S}$ rRNA, beta-actin and glyceraldehyde-3-phosphate-dehydrogenase for normalization in real-time quantitative reverse transcriptase-polymerase chain reaction analysis of gene expression in human T lymphocytes. Scand J Immunol 2004;59:566-573.

24. Ros JE, Roskams TA, Geuken M, et al. ATP binding cassette transporter gene expression in rat liver progenitor cells. Gut 2003;52:1060-1067.

25. Roelofsen H, Hooiveld GJ, Koning H, Havinga R, Jansen PL, Muller M. Glutathione S-conjugate transport in hepatocytes entering the cell cycle is preserved by a switch in expression from the apical MRP2 to the basolateral MRP1 transporting protein. J Cell Sci 1999; 112(pt 9):1395-1404.

26. Fiegel HC, Lioznov MV, Cortes-Dericks L, et al. Liverspecific gene expression in cultured human hematopoietic stem cells. Stem Cells 2003;21:98-104. 